\title{
LEI MARIA DA PENHA E CÔNJUGES MILITARES: PROTEÇÃO DA MULHER E DOS VALORES DA CASERNA.
}

\section{MARIA DA PENHA LAW AND MILITARY SPOUSES: THE PROTECTION OF WOMEN AND THE VALUES OF BARRACKS.}

Ranna Rannuai Rodrigues Silva ${ }^{1}$

\section{RESUMO}

O presente artigo suscita a questão da violência doméstica e familiar entre cônjuges militares, refletindo sobre a Lei Maria da Penha, sobre o aumento do efetivo feminino nas instituições militares e o aumento da formação de casais militares. São abordados os principais aspectos da legislação especial em tela, a inserção das mulheres na caserna e a posição das doutrinas e jurisprudência dos principais tribunais acerca da competência para julgamento dos casos de violência doméstica e familiar entre cônjuges militares. A finalidade aqui é trazer à tona a reflexão sobre a adequada proteção da mulher nessas situações e observar, ainda, quando a violência contra a mulher atingiria também os bens jurídicos da caserna, para assim, definir a competência para julgamento.

PALAVRAS-CHAVE: Lei Maria da Penha; Violência doméstica e familiar; Efetivo feminino; Cônjuges militares; Competência da Justiça Militar.

\section{ABSTRACT}

This article raises the question of domestic and family violence between military spouses, reflecting on the 10 years of the Maria da Penha Law and looking at the increase in the number of women in military institutions, as well as increasing military couples. The main aspects of the special legislation on the subject, the insertion of women in the barracks and the position of doctrines and jurisprudence of the main courts on the competence to judge cases of domestic and family violence between

\footnotetext{
${ }^{1}$ Especialista em Processo Penal e Direito Penal Militar pela Universidade Cândido Mendes. Advogada. E-mail. ranna.rodrigues@hotmail.com
} 
military spouses will be addressed. The purpose here is to bring to light the reflection on the adequate protection of women in these situations and also to observe when violence against women also affects the legal assets of the barracks, in order to define the competence for judgment.

KEYWORDS: Maria da Penha Law; Domestic and family violence; Effective female; Military spouses; Military Justice Competence.

\section{INTRODUÇÃO}

A partir do processo de redemocratização do Estado brasileiro, a posição social e profissional feminina vem sendo repensada e transformada. Ao longo desse processo, e até o presente momento, vem acontecendo a gradual inserção feminina no âmbito da caserna, avolumando-se o efetivo feminino. Primeiro em cargos administrativos e, mais recentemente, com a possibilidade de assumirem cargos de combatentes. Nesse contexto, é natural que vínculos afetivos sejam estabelecidos, e casais, em que ambos os cônjuges são militares, sejam formados.

Se por um lado, assegura-se a liberdade profissional feminina, ampliando sua participação no meio militar, por outro lado depara-se com a problemática, em todo meio social, de assegurar a proteção às mulheres vítimas de violência de gênero no âmbito doméstico e familiar. Como dito, essa questão permeia toda sociedade, tal como atinge alguns casais de militares que vêm se formando ao longo do processo explicado.

No ano de 2006, surge a Lei Maria da Penha, legislação especial que traz inovações para o direito penal, para o processo penal e medidas protetivas que se destinam a proteger de forma célere e eficaz as mulheres vítimas de violência doméstica e familiar. Em paralelo e tutelando os bens jurídicos das instituições militares, existe, no Poder Judiciário, o ramo especializado da Justiça Militar, seja da União ou dos Estados.

Dito isso, o presente trabalho irá explanar o conflito de competência que se estabelece entre a Justiça comum, com a Lei Maria da Penha, e a Justiça Militar, para 
julgamento dos casos de violência doméstica e familiar entre cônjuges militares. Analisar-se-á, inicialmente, os principais aspectos da Lei Maria da Penha; a seguir, serão apresentados um breve histórico e a situação atual das mulheres nas instituições militares; e, por fim, serão abordados os entendimentos específicos da doutrina e jurisprudência sobre tal questão, na tentativa de buscar a tutela jurídica mais adequada para a mulher vítima dessa violência.

Para tanto, a metodologia de pesquisa será baseada na pesquisa teórica, de cunho bibliográfico, socorrendo-se das fontes imediatas de pesquisa - jurisprudência e doutrina - que o arcabouço jurídico permitir, utilizando-se, ainda, de literaturas que contribuam para o trabalho. Será utilizada também pesquisa prescritiva, considerandose a melhor solução para a problemática, com a linha de pesquisa dogmática.

Por derradeiro, é válido ressaltar que o presente estudo não tem o intuito de esgotar o assunto, mas sim fomentar o debate sobre o conflito de competência e o melhor caminho para solucioná-lo.

\section{ASPECTOS GERAIS E IMPORTANTES DA LEI MARIA DA PENHA}

A Lei 11.340/06, mais conhecida como Lei Maria da Penha (BRASIL, 2006), teve como marco de seu advento o caso da biofarmacêutica Maria da Penha Maia Fernandes, vítima de duas tentativas de homicídio por parte de seu cônjuge. $\mathrm{Na}$ primeira agressão, ela foi alvejada com um tiro nas costas e ficou paraplégica e, na segunda, foi empurrada da cadeira de rodas pelo marido que tentou eletrocutá-la no chuveiro. Conforme noticiado pela Folha de São Paulo, em maio de 2001, haja vista a morosidade da justiça brasileira em processar, julgar e punir o marido agressor e após 15 anos sem desfecho, o caso foi levado à Comissão Interamericana de Direitos Humanos da Organização dos Estados Americanos - OEA que, no relatório 54 de 2001, condenou o Brasil por omissão em relação à violência doméstica em geral e, especificamente, em relação ao ocorrido com a biofarmacêutica. Resultou do julgamento da OEA a recomendação para o Brasil criar uma legislação específica e 
adequada para as situações de violência doméstica e a prisão do agressor de Maria da Penha. Antes da edição da lei especial em tela, o país subscreveu a Convenção Interamericana para prevenir, punir e erradicar a violência contra a mulher (BRASIL, 1994) - informalmente conhecida como Convenção de Belém do Pará - que estabelece em seu artigo primeiro: "entender-se-á por violência contra a mulher qualquer ato ou conduta baseada no gênero, que cause morte, dano ou sofrimento físico, sexual ou psicológico à mulher, tanto na esfera pública como na esfera privada".

A Lei Maria da Penha define as formas de violência - física, psicológica, sexual, patrimonial, moral - e provoca importantes mudanças no ordenamento jurídico, que visam tornar a prevenção e a repressão da violência contra a mulher mais eficazes. Assim, realizada a notícia da agressão à autoridade policial, esta informará ao juiz, dentro de 48 horas, o qual deverá decidir, também em prazo de 48 horas: pela aplicação de medidas protetivas, pelo encaminhamento da ofendida a órgão de assistência judiciária e pela comunicação ao Ministério Público, para que adote as providências cabíveis.

As medidas protetivas podem impor obrigações ao agressor como: suspensão da posse ou restrição do porte de armas e afastamento do lar ou local de convivência com a ofendida. O descumprimento pelo agressor é crime, tipificado no artigo 24-A da Lei 11.340/06, com pena de detenção de 3 meses a 2 anos. Ainda, existem as medidas destinadas à vítima: encaminhamento a programas de proteção, separação de corpos, etc.

A lei especial tem no seu cerne a ideia da violência de gênero dirigida contra a mulher. Assim, o sujeito passivo a quem a Lei Maria da Penha destina especial proteção é a mulher, não albergando homens e a violência deve ser praticada no contexto de relações íntimas, domésticas e familiares.

O sujeito ativo, o agressor, por sua vez, pode ser homem ou mulher, independente da orientação sexual dos sujeitos, conforme parágrafo único do artigo $5^{\circ}$ 
da referida lei: "As relações pessoais enunciadas neste artigo independem de orientação sexual."

Justificando a lei especial para a mulher, a juíza do estado de Mato Grosso, Amini Haddad (2015, p.1) afirma:

A lei 11.340/2006 considera todo um contexto histórico e cultural de desvalorização da mulher que remonta aos primórdios da humanidade. A Lei Maria da Penha surgiu como um marco histórico na tentativa de resgatar o valor das mulheres e de combater a chamada violência de gênero, que é a violência que ocorre contra a mulher justamente por ser mulher.

De maneira acertada e acompanhando as mudanças da sociedade e a evolução legal do conceito de família, a lei alcança a união homoafetiva. A Dra. Maria Elizabeth Rocha (2015, p.3) explica:

No Brasil, a questão foi enfrentada pelo Supremo Tribunal Federal na ADI no 4277 e na ADPF no 132 que ampliou a tradicional união entre homem e mulher. Nesse sentido, a Lei Maria da Penha constitui legislação de vanguarda, porquanto o parágrafo único do art. $5^{\circ}$ reproduz texto inovador ao estabelecer, pela primeira vez no sistema positivo, preceituação entre parceiras do mesmo sexo e, ressalve-se, antes da paradigmática decisão da Suprema Corte.

A inovadora legislação tem a finalidade de tutelar com maior rigor e eficiência a questão da violência doméstica e familiar contra a mulher e ampara-se no artigo 226, $\S$ 8o, da Constituição Federal (BRASIL, 1988), na Convenção sobre a Eliminação de Todas as Formas de Discriminação contra as Mulheres (ONU, 1979; ratificada pelo Brasil em 1984) e na Convenção Interamericana para Prevenir, Punir e Erradicar a Violência contra a Mulher (BRASIL, 1994).

Todavia, a conformidade da Lei Maria da Penha com a Constituição Federal foi questionada, e o Supremo Tribunal Federal (STF), na Ação Direta de Constitucionalidade (ADC) 19 (STF, 2012a), ajuizada pela Presidência da República, por votação unânime, declarou a constitucionalidade dos artigos 1ำ 33 e 41 da Lei 11.340/2006. No tocante ao amparo da mulher pela lei especial, o relator da ADC 19 afirmou "que o ordenamento jurídico brasileiro prevê tratamento distinto e proteção 
especial a outros sujeitos de direito em situação de hipossuficiência, como é o caso do idoso, da criança e do adolescente".

O artigo 33 da Lei 11.340/2006, por sua vez, afirma que "enquanto não estruturados os Juizados de Violência Doméstica e Familiar contra a Mulher, as varas criminais acumularão as competências cível e criminal [...]. Em análise do referido dispositivo, o relator evidenciou que não há a imposição de criação de juizados especializados, mas sim uma faculdade de criação, a fim de que a questão seja processada e julgada de maneira eficiente e efetiva.

Houve, também, o julgamento da Ação Direta de Inconstitucionalidade - ADI 4424 (STF, 2012b), ajuizada pelo Procurador-Geral da República, que determinou a ação pública incondicionada nos crimes de lesão corporal leve e que não se aplica a Lei 9.099/95 (BRASIL, 1995) - Lei dos Juizados Especiais - nos crimes de violência doméstica, visto não serem mais entendidos como crimes de menor potencial ofensivo. Vide o artigo 41 da Lei Maria da Penha, in verbis: "Aos crimes praticados com violência doméstica e familiar contra a mulher, independentemente da pena prevista, não se aplica a Lei 9.099, de 26 de setembro de 1995".

Ademais, das outras decisões relevantes da Suprema Corte em relação à Lei Maria Penha: nas Reclamações - RCL 20367, RCL 19525 e RCL 18391- o STF reafirmou a desnecessidade de representação e o interesse da ofendida, bem como, a legitimidade do Ministério Público para promover a ação penal. No Habeas Corpus 130124, impossibilitou a aplicação do princípio da bagatela em situação de crimes cometidos com violência doméstica e, no Habeas Corpus 129446, rechaçou a possibilidade de substituição de pena privativa de liberdade por restritiva de direitos.

O Superior Tribunal de Justiça, por seu turno, também produziu significativo arcabouço jurisprudencial, compilado na edição 41 da Jurisprudência em Teses (STJ, 2015). Destacam-se: "A violência doméstica abrange qualquer relação íntima de afeto, dispensada a coabitação"; "Para a aplicação da Lei n. 11.340/2006, há necessidade de demonstração da situação de vulnerabilidade ou hipossuficiência da mulher, numa 
perspectiva de gênero"; "A agressão do namorado contra a namorada, mesmo cessado o relacionamento, mas que ocorra em decorrência dele,está inserida na hipótese do art. 5o, III, da Lei n. 11.340/06, caracterizando a violência doméstica"; "A suspensão condicional do processo e a transação penal não se aplicam na hipótese de delitos sujeitos ao rito da Lei Maria da Penha (Súmula 536 do STJ)."

Ao longo dos 12 anos de vigência da legislação especial referida, a jurisprudência relativa ao tema foi sendo enunciada pelos Tribunais, trazendo esclarecimento sobre a aplicação da norma. Ademais, foram incorporadas outras normas ao texto legal original, a fim de ajustar a Lei à realidade social e abarcar as demandas e situações não previstas.

\section{EFETIVO MILITAR FEMININO E CÔNJUGES MILITARES}

A Constituição Federal dispõe sobre as Forças Armadas - artigos 142 e 143 - e sobre as instituições militares estaduais - artigo 144, V - e traz, no rol dos direitos fundamentais, a previsão de que homens e mulheres são iguais em direitos e obrigações - artigo $5^{\circ}$, I. As constatações anteriores expressam a importância das instituições militares e de seus efetivos, assuntos primados pelo legislador constituinte; bem como a consolidação, logo no primeiro inciso do artigo $5^{\circ}$, da isonomia entre homens e mulheres.

Importante lembrar que o princípio da isonomia tem dupla aplicação - igualdade formal e igualdade material - conforme explicam Vicente Paulo e Marcelo Alexandrino (2015, p.123): "O princípio da igualdade determina que seja dado tratamento igual aos que se encontram em situação equivalente e que sejam tratados de maneira desigual os desiguais, na medida de suas desigualdades". Com base na igualdade material, ampara-se a proteção especial à mulher vítima de violência familiar e doméstica. É a lição de Maria Berenice Dias (2007, p.1): "Não ver que a Lei Maria da Penha consagra o princípio da igualdade é rasgar a Constituição Federal, é não conhecer os números da violência doméstica, é revelar indisfarçável discriminação contra a mulher...". 
À medida que a sociedade evolui, e a mulher ganha mais espaço de atuação em diversos setores da sociedade, a Constituição preocupa-se em tutelar e garantir essa inserção feminina, sem diferenciações arbitrárias e discriminatórias com os indivíduos do sexo masculino. $O$ aumento progressivo de militares do sexo feminino nas Forças Armadas $^{5} \mathrm{e}$ nas instituições militares estaduais é um dos reflexos dessas conquistas, da evolução do paradigma da estrutura social, política e econômica e da importância do papel das referidas instituições, nas quais muitas mulheres ao longo dos tempos desejaram e desejam ingressar, conforme se observa na tabela abaixo, extraída do trabalho "Mulheres nas Forças Armadas brasileiras: situação atual e perspectivas futuras" (ALMEIDA, 2015, p.14):

Quadro 2 - Grau de interesse das mulheres pelas Forças Armadas

\begin{tabular}{|c|c|c|}
\hline $\begin{array}{c}\text { Força } \\
\text { Armada }\end{array}$ & Concurso & $\begin{array}{c}\text { Percentual de } \\
\text { mulheres inscritas }\end{array}$ \\
\hline \multirow{2}{*}{$\begin{array}{l}\text { Marinha do } \\
\text { Brasil }\end{array}$} & Escola Naval $^{11}$ & 39,5 \\
\hline & Corpo Auxiliar de Praças & 61,8 \\
\hline \multirow{5}{*}{$\begin{array}{l}\text { Exército } \\
\text { Brasileiro }\end{array}$} & Instituto Militar de Engenharia & 28,9 \\
\hline & Escola de Saúde do Exército & 63,2 \\
\hline & Escola de Formação Complementar do Exército & 48,7 \\
\hline & Escola de Sargentos das Armas - Músicos & 16,0 \\
\hline & Escola de Sargentos das Armas - Saúde & 78,9 \\
\hline \multirow{4}{*}{$\begin{array}{c}\text { Força Aérea } \\
\text { Brasileira }\end{array}$} & Academia da Força Aérea & 28,8 \\
\hline & Escola de Especialistas de Aeronáutica - CFS-B ${ }^{12}$ & 35,5 \\
\hline & Escola de Especialistas de Aeronáutica - EAGS-B ${ }^{13}$ & 46,8 \\
\hline & Escola de Especialistas de Aeronáutica - EAGS-ME ${ }^{14}$ & 54,4 \\
\hline
\end{tabular}

Todavia, como se depreende do trabalho "Mulheres e a vida militar", a inserção feminina na caserna não foi acompanhada, na prática, pela igualdade material de gêneros, vez que "a incorporação das mulheres às forças armadas não foi precedida da revolução na percepção de papéis sociais representados pela adoção de posturas de igualdade de gênero" (ADÃO; MATHIAS, 2013, p.7) 
No âmbito federal, segundo dados do Governo Federal, as Forças Armadas contam com 25.898 mulheres, representando $7 \%$ do efetivo total de militares federais. No ano de 2012, foi promovida na Marinha, a primeira oficial-general - Almirante Médica Dalva Maria Carvalho Mendes - ao posto de Contra-Almirante. A Força Aérea Brasileira, por seu turno, teve como marco no ano de 2015 a passagem de comando de uma de suas organizações militares a Coronel Médica Carla Lyrio Martins e a Força Terrestre terá, a partir de 2017 e pela primeira vez, a admissão de mulheres para formação na área de combate ${ }^{2}$.

Com relação às instituições militares estaduais, estudo sobre as mulheres nas instituições de segurança (composta também por órgãos policiais não militarizados) ${ }^{3}$ da Secretaria Nacional de Segurança Pública (Brasil. 2013. P.11) afirma que ${ }^{4}$

No Brasil, a bibliografia aponta que o acesso das mulheres às polícias civis e militares passou a ser ampliado a partir dos anos 1980 - no contexto de redemocratização política - e, especialmente, a partir de 1988, com a promulgação da Constituição Federal (BRASIL, 1988), marco para a consolidação da democracia no país.

Ainda, o estudo observa que os Corpos de Bombeiros eram vinculados às Polícias e apenas no final dos anos 1990 teve início a separação das instituições. No ano da realização do referido estudo restou constatado que "nas polícias militares e bombeiros militares predominam praças - $86,6 \%$ e $72,67 \%$, respectivamente, entre as quais as soldados correspondem à maioria nas duas corporações: são 40,07\% entre as PS e $61 \%$ entre as policiais militares" (Brasil, 2013, p.30).

O aumento gradual da participação das mulheres na caserna, majoritariamente compostas por homens, gerou maior convivência entre militares de sexos opostos e,

\footnotetext{
${ }^{2}$ Disponível em: <http:/www.brasil.gov.br/cidadania-e-justica/2016/03/mulheres-vencem-resistencias-historicas-econquistam-espaco-nas-forcas-armadas>. Acesso em: 4 nov. 2016

${ }^{3}$ A Carta Magna prevê no seu artigo 144 que a segurança pública será exercida pela polícia federal, polícia rodoviária federal, polícia ferroviária federal, polícias civis, polícias militares e corpos de bombeiros militares. Como a própria nomenclatura já aponta, apenas as duas ultimas instituições são militares, organizadas com base na hierarquia e disciplina

4 Disponível em:<http://bibspi.planejamento.gov.br/handle/iditem/299>. Acesso em: 4 nov. 2016.
} 
por consequência, aumento das relações conjugais e familiares estabelecidas entre eles. Ainda do trabalho "Mulheres e a vida militar", observa-se que "há outra forma, mais tradicional, de pertencimento das mulheres às forças armadas, que é o mundo das esposas. A novidade contemporânea é quando esta esposa é também militar". (ADÃO; MATHIAS, 2013, p.17).

Nesse contexto, e em contraste com o aspecto positivo da inserção feminina no meio militar, é que está presente a questão da violência doméstica e familiar contra a mulher, quando esta é militar e seu agressor também. Esse parece não atender a seu próprio regime jurídico, disposto no Estatuto dos Militares, quando diz que devem ser observados, dentre outros, os preceitos de ética militar de respeito à dignidade da pessoa humana, garantia de assistência moral e material ao seu lar e comportamento de chefe de família modelar, vide artigo 28, incisos III e XV da Lei oㅜ 6.880/80.

As instituições militares, encaradas como instituições imbuídas de disciplina e altos valores éticos e morais e que detêm as primorosas missões de defesa da Pátria de competência das Forças Armadas - e de zelar pela segurança pública - de competência das instituições de segurança- carregam consigo a manutenção do próprio Estado Democrático de Direito, seus fundamentos e princípios. Dentre eles, os direitos fundamentais da dignidade da pessoa humana, liberdade e igualdade.

Destarte, nada mais coerente e exemplar do que tais instituições seguirem na direção de ampliar cada vez mais seus efetivos femininos, bem como ampliar o debate e a implementação de políticas com vistas a superar discriminações de gênero infundadas e a valorizar a mulher como profissional militar. Já existe esforço do Ministério da Defesa nesse sentido que em 2014 instituiu sua Comissão de Gênero com caráter consultivo e com o objetivo de estudar e propor ações de efetivação dos direitos das mulheres e da igualdade de gênero dentro das Forças Armadas.

Dentro do cenário da Lei Maria da Penha e da violência doméstica e familiar nas relações íntimas entre militares, surge a discussão de como proceder na aplicação da referida lei e do direito penal militar. Nesses casos, há também crime militar e de 
consequente competência da justiça militar? Qual legislação deve ser aplicada? Qual o posicionamento da doutrina e dos Tribunais Superiores? Os questionamentos serão discutidos a seguir.

\section{VIOLÊNCIA DOMÉSTICA ENTRE CÔNJUGES MILITATES E COMPETÊNCIA PARA JULGAMENTO}

Agora, abordar-se-á especificamente a problemática entre a aplicação da Lei Maria da Penha e do Código Penal Militar (Decreto-Lei n 1001 de 21 de outubro de 1969) quando há violência doméstica e familiar entre cônjuges militares. Nas palavras de Célio Lobão (2006, p.121-122): "Com a incorporação de mulheres às Forças Armadas, à Polícia Militar e ao Corpo de Bombeiros Militares, surge o problema relativo à competência da Justiça Militar para conhecer do delito cometido por um cônjuge ou companheiro contra outro".

Na esfera jurídica, a Constituição Federal prevê que o dever de tutela dos delitos que afrontam as instituições militares é de competência da Justiça Militar da União, no caso das Forças Armadas; ou das Auditorias Militares Estaduais, no caso dos Bombeiros e da Polícia Militar. É certo que quando os sujeitos passivo e ativo de uma conduta delituosa são militares da ativa, em regra, configura-se hipótese de crime militar, conforme disposição legal do Código Penal Militar (Decreto-Lei n 1001 de 21 de outubro de 1969):

Art. 9 Consideram-se crimes militares, em tempo de paz: II - os crimes previstos neste Código, embora também o sejam com igual definição na lei penal comum, quando praticados: a) por militar em situação de atividade ou assemelhado, contra militar na mesma situação ou assemelhado;

Cumpre observar que a figura do assemelhado 5 não existe mais. Todavia, existem servidores públicos civis nas Forças Armadas e nas Forças Auxiliares. Parte da doutrina baseia-se apenas no aspecto estritamente legal e afirma que em decorrência

\footnotetext{
${ }^{5} \mathrm{O}$ assemelhado era o servidor público que prestava seus serviços em instituições militares e, embora civil, era submetido ao regime jurídico dos militares. Assim, respondia de acordo com o regulamento disciplinar aplicado aos militares. Atualmente, os servidores em atuação nessas instituições são regidos pelo estatuto dos servidores civis.
} 
de tal dispositivo, havendo sujeitos ativo e passivo militares da ativa no cometimento de um delito, será crime militar, logo de competência da Justiça Militar. Dessa forma, tendo como base somente o critério ratione personae, o delito de violência praticado por cônjuge militar contra cônjuge militar do sexo feminino seria de competência da justiça especializada, em razão de ambos sujeitos serem militares da ativa. $O$ processo não declinaria para a justiça comum, a qual compete a aplicação da Lei Maria da Penha.

Contudo, na lição do Promotor da Justiça Militar Jorge César de Assis (2015, p.10),

\begin{abstract}
Nem todo fato delituoso ocorrido entre militares constitui crime militar. A caracterização do crime militar não se resume a este dado objetivo, autor e vítima serem militares da ativa, devendo ser considerada a efetiva ofensa à instituição militar, que os defensores da 1a teoria preferem passar ao largo. Com efeito, levada à risca, ou seja, aceita a ideia que uma lesão corporal causada pelo marido militar, dentro de casa, contra a mulher militar, por um motivo doméstico constitui crime militar implica em aceitar que, mesmo no seio de seu lar, o cônjuge (companheiro) de menor posto ou graduação tenha que pedir permissão para sentar-se ou retirar-se da mesa já que isto é uma regra essencial da disciplina prevista nos regulamentos de honras e sinais de respeito, e sua violação constitui transgressão. (Grifo nosso)
\end{abstract}

Desse ponto, já se traz à tona a segunda corrente adepta da total aplicação da Lei Maria da Penha, retirando-se a competência da Justiça Militar nesses casos. É pautada no direito fundamental de inviolabilidade da vida privada, da intimidade e da casa, previsto no artigo $5^{\circ}$ da Carta Magna. Destarte, no assunto relativo à instituição familiar, não caberia a aplicação do Código Penal Militar com a justificativa de manutenção da regularidade das instituições militares e seus princípios basilares. Célio Lobão (2006, p.121-122) afirma que "se a ocorrência diz respeito à vida em comum, permanecendo nos limites da relação conjugal ou de companheiros, sem reflexos na disciplina e na hierarquia militar, permanecerá no âmbito da jurisdição comum".

Compactuando com esse posicionamento, Maria Elizabeth Teixeira (2015, p. 6,7) ensina que: leis especiais e regulamentarem tipos penais afins nos crimes contra a pessoa, 
poder-se-ia supor um aparente conflito de normas constitucionais e/ou legais. Não é o caso. Isso porque, para um crime ser considerado de natureza militar, mister a afronta aos princípios fundamentais norteadores da ordem, disciplina e hierarquia das Forças Armadas. (...) A não prevalência desse entendimento vulnera a garantia fundamental necessária à intimidade pessoal e à liberdade humana. Pior, fere de morte o princípio da isonomia em face da consequente distinção entre a mulher civil e a militar, porquanto as medidas protetivas e a penalização do agressor de modo mais gravoso, oriundas da novel legislação, não são aplicáveis na Jurisdição Milicien .(Grifo nosso)

Por derradeiro, Marcello Streifinger e Robson Coimbra (2012, p. 139), em seu Manual de Direito Penal Militar, ratificam tal vertente doutrinária, asseverando que:

Seguindo o avanço democrático, o militar adquiriu mais liberdade diante do rígido ordenamento jurídico militar - tal rigidez faz-se necessária apenas para manter a regularidade das forças militares, mas desnecessária na intimidade e na vida privada do militar. Caso o militar desrespeite essa liberdade e venha a cometer violência doméstica contra sua companheira também militar, e esta requerer intervenção estatal, deverá então ser aplicada a Lei Maria da Penha... (2012, p. 139). (Grifo nosso)

Diametralmente oposto é o pensamento do Promotor de Justiça Militar, Adriano Alves-Marreiros (2015, p. 4), que critica a afirmação de que os bens jurídicos da hierarquia e disciplina não seriam atingidos, alegando que

É evidente que a possibilidade de não repercutir no trabalho é mínima e, em um quartel, ainda menor, e isso afeta a hierarquia e disciplina, pois a agressão entre dois militares, ainda mais quando se tratar de um casal é algo a ser coibido, pois fere o pundonor militar e o decoro da classe por atingir a essência da família. (Grifo nosso)

Alinhado ao entendimento supracitado, Guilherme Nucci (2014, p. 48)

Em qualquer cenário, o militar que agride o militar, ambos na ativa, deve ser julgado na Justiça castrense. Não vemos diferença para tal finalidade se o militar-marido lesiona a militar-esposa dentro do quartel ou dentro da residência comum do casal. Trata-se de crime militar, embora reconheçamos a tendência de se deixar fora do âmbito militar as agressões existentes do cenário doméstico. 
Nesse sentido, também, é o posicionamento do Superior Tribunal Militar, como se observa da jurisprudência da referida Corte:

APELAÇÃO DEFENSIVA. VIOLÊNCIA CONTRA SUPERIOR.PRELIMINARES. INCOMPETÊNCIA DA JMU PARA PROCESSAR E JULGAR CIVIS. (...) OFENDIDO SUPERIOR E EX-NAMORADO DA RÉ. INDISPONIBILIDADE DOS POSTOS E DAS GRADUAÇÕES. REPULSA A AGRESSÃO NÃO COMPROVADA. LEI № 11.340/06 E CONVENÇÕES PREQUESTIONADAS. INEXISTÊNCIA DE VIOLAÇÃO. RECURSO NÃO PROVIDO. DECISÃO UNÂNIME. Para a competência da Justiça Militar da União (JMU), basta que os militares, agente e vítima, sejam da ativa à época do crime castrense, independentemente de comporem a mesma unidade familiar, de saberem da condição um do outro e do local do delito. (...) Nos crimes castrenses praticados entre casal de militares, a competência da JMU deve ser mantida. 0 móvel dos agentes, no sentido de terem ou não a consciente intenção de ofender as instituições militares, e o local do crime não perfazem condições insertas no art. 9, inciso II, alínea a, do CPM, pois sempre há repercussões intramuros, inclusive eles têm a previsibilidade das consequências de seus atos. Erra quem, para definir a competência da Justiça Militar da União, se reduza à análise superficial de os agentes terem ou não a consciente intenção de ofender as instituições militares. Se há agressões, mesmo entre casais em suas residências, obviamente que, tão logo a notícia adentre os portões de $\mathrm{OM}$, dá-se o abalo às instituições, aspecto sob a total previsibilidade dos agentes. Há fatos ocorridos entre militares em suas residências que podem ser bem mais nefastos às Instituições Castrenses do que outros dentro de uma OM.(...). Recurso da Defesa não provido. Decisão unanime ${ }^{6}$ (Grifo nosso)

Pois bem, o militar, homem ou mulher, ao vestir a farda, dispõe a sua vida em prol das suas nobres missões constitucionais que visam bens maiores, sejam da pátria ou da sociedade. Em que pese sua total dedicação, antes do militar, há que se ter em mente o ser humano, o cidadão que ali se figura. Assim, a ele devem ser assegurados os direitos fundamentais, excluídos apenas aqueles que necessariamente prejudicariam a regularidade das instituições militares, os seus princípios, a estrutura e os fins a que se destinam. Até porque, abaladas as estruturas das instituições militares, abalar-se-ia a própria estrutura do Estado Democrático de Direito.

\footnotetext{
${ }^{6}$ Superior Tribunal Militar, Apelação 00000472420147120012/AM, rel. Min. Marco Antônio de Farias, julgado em 17 ago 2016, DJe 29 ago 2016.
} 
Aqui, alega-se que a busca pelo equilíbrio é necessária e, felizmente, há movimento nessa direção. Dessa forma, parece acertado que, no caso de violência doméstica e familiar entre cônjuges militares, não há intenção, em regra, de se atentar contra os princípios e valores castrenses. A vida privada do casal e suas questões de foro íntimo dizem respeito aos indivíduos em questão e não às suas organizações militares. Não é sem razão que a Administração Militar não alcança o interior das residências de militares, mesmo em Próprio Nacional Residencial (PNR) ou vilas militares.

Terceira vertente doutrinária, trazida por Fernando Kobal (Apud Neves e Streifinger, 2012, p. 377) buscou uma conciliação entre a tutela dos bens jurídicos castrenses e a tutela da mulher em situação de violência a ser amparada pelos dispositivos da Lei Maria da Penha. Dessa forma, o crime seria considerado militar impróprio- aquele que pode ser praticado pelo militar, bem como, pelo civil - processado e julgado perante a Justiça Militar, a qual, todavia, poderia se valer e se utilizar das medidas protetivas e de urgência previstas na lei especial.

Segue também esse entendimento Abelardo Júlio da Rocha - oficial da Polícia Militar do Estado de São Paulo. (Neves e Streifinger, 2012, p. 378). As medidas protetivas de urgência trazidas pela Lei Maria da Penha, elencadas nas palavras de Maria Elizabeth Teixeira (2015, p.5), são:

No tocante às medidas protetivas de urgência, cujo rol não é taxativo, impõe-se ao ofensor: 1) a suspensão da posse ou restrição do porte de armas; 2) o afastamento do lar, domicílio ou local de convivência da vítima; 3) a proibição de determinadas condutas, tais como aproximação da ofendida, de seus familiares e das testemunhas, fixando o limite mínimo de distância entre eles; 4) o contato com a mulher vitimizada, seus familiares e testemunhas por qualquer meio de comunicação; 5) a restrição ou suspensão de visitas aos dependentes menores; e 6) a prestação de alimentos provisionais ou preventivos.

Por seu turno, as medidas de urgência deferidas à ofendida são: 1) encaminhála e seus dependentes a programa oficial ou comunitário de proteção ou atendimento; 2) determinar sua recondução e de seus dependentes ao respectivo domicílio, após o afastamento do agressor; 3) resguardar seu afastamento do lar sem prejuízo dos direitos relativos a bens, guarda dos filhos e alimentos; 4) determinar a separação de corpos; 5) restituir-Ihe o patrimônio indevidamente subtraído pelo agente ativo; 6) proibir temporariamente a 
celebração de atos e contratos de compra, venda e locação de propriedade comum, salvo expressa autorização judicial; 7) suspender as procurações conferidas pela mulher ao parceiro; e 8) a prestação de caução provisória, mediante depósito judicial, por perdas e danos decorrentes da prática de violência doméstica e familiar.

As referidas medidas de cunho cautelar ora obrigam o agressor, ora resguardam a vítima. Em todo caso, visam proteger a mulher de novas agressões ou ameaças, buscando garantir sua integridade, em todos os aspectos.

Em regra, parece mais acertado o posicionamento de conferir competência à Justiça Comum, uma vez que, a priori, a agressão no bojo de relações íntimas entre militares não tem o condão de ferir a regularidade das instituições militares e nem se intenta atingir uma militar da ativa, mas a mulher com a qual o agressor tem vínculo afetivo, ficando excluída assim, nesse caso, a competência da Justiça Militar. Ainda, nos ensinamentos de Maria Elizabeth (2015, p.6), quanto às mulheres que são militares, ela diz que

o fato de elas ostentarem o status de militar não impede que sejam vítimas de abusos cometidos por cônjuges ou companheiros, igualmente militares, no seio familiar. (...) mulheres fardadas atacadas por maridos ou companheiros de caserna, na intimidade do lar, encontram-se albergadas pela Lei Maria da Penha.

Não obstante a regra geral defendida acima, evidente é que deve ser avaliado o caso concreto para pontuar essa discussão e estabelecer a aplicação do dispositivo legal mais adequado. Em algumas situações, o fato delituoso contra a mulher poderá sim aviltar bens jurídicos próprios da caserna. Nesse ponto, a doutrina de Kobal (Apud Neves e Streifinger, 2012, p. 377), explanada acima, parece pertinente: quando a conduta delituosa do militar agressor afrontar a regularidade das instituições militares, deverá tutelar o conflito, a Justiça Militar, aplicando o Código Penal Militar e os institutos protetivos da Lei Maria da Penha.

Nesse raciocínio, Marcello Streifinger e Robson Coimbra (2012, p. 140): 
da necessidade de intervenção penal militar. (...) Claro que se a agressão for perpetrada em ambiente onde estejam presentes a disciplina e a hierarquia militares, haverá assinte a bens jurídicos tutelados pelo Direito Penal Militar... (Grifo nosso).

Jorge César de Assis $(2015$, p. 16, 17) apresenta dois exemplos, um do Tribunal de Justiça Militar do Rio Grande do Sul e outro da Justiça Militar da União, especificamente na Auditoria da 8 ${ }^{\text {a }}$ Circunscrição Judiciária Militar, em Belém-PA que exemplificam situações de violência doméstica contra a mulher, nas quais a Corte considerou que houve, também, afronta à caserna

No primeiro caso, ainda que impulsionado por inconformismo frente a uma possível separação, veremos que o réu, Sargento da ativa que havia agredido sua companheira, uma Capitã, algemando-a na via pública. Ao ser abordado por PMs que foram chamados por vizinhos, identificou-se como sargento da Brigada acreditando que seria liberado. Para o TJM-RS, não se trata de mera pendenga familiar quando essa extrapola as fronteiras da privacidade e torna-se pública.(...) (Grifo no original). (LESÃO CORPORAL, VIOLÊNCIA CONTRA SUPERIOR E CONTRANGIMENTO ILEGAL. TJMRS, Ap. crim. 3.785/05, relator Juiz-Cel Sérgio Antonio Berni de Brum, julgado em 09.11.2005.)

Finalmente, não poderíamos deixar de trazer a lume um fato concreto, com a aplicação da teoria conciliadora, acontecido recentemente no primeiro grau da Justiça Militar da União(...) uma $2^{\circ}$ tenente, estacionou seu veículo em frente à Seção Telemática da Base Aérea de Belém. Cerca de 15 minutos após estacionar seu carro, a oficiala fora informada que um $2^{\circ}$ sargento, seu ex companheiro, ora denunciado, teria utilizado um martelo para danificar o parabrisa de seu veículo e jogado substância inflamável no veículo. Considerado crime militar, sem qualquer sombra de dúvida48, o agente foi incursionado no art. 261, II, CPM (dano qualificado pelo uso de substância inflamável, sujeito a uma pena de reclusão de até 4 anos, se o fato não constituir crime mais grave. $\mathrm{Na}$ sala da Auditoria, durante a audiência de qualificação e interrogatório seguiu-se a oitiva da ofendida, que expressou sentir-se ameaçada pelo réu, que trabalhava na mesma Organização Militar, e que já teria aparecido, sem motivo justificável no colégio do filho pequeno da tenente. Com parecer favorável do Ministério Público Militar, naquela audiência, o réu: a)teve suspenso o direito de porte de arma (art. 22, I, LMP); b) foi transferido para outra OM (art. 22, II, LMP); c) foi proibido de ter contato com a ofendida e sua família (art. 22, III, LMP). Ainda que considerado 0 fato delituoso como crime militar, considerou-se, na oportunidade, que a ofendida corria riscos à sua integridade e de seu filho menor, razão pela qual, o Conselho de Justiça, deferiu as medidas protetivas de urgência, em uma perfeita aplicação da Lei Maria da Penha na Justiça Militar. (Grifo nosso) 
Observa-se, a seguir, decisões da Suprema Corte, nesse sentido. No julgamento do Habeas Corpus 125836 (São Paulo), o STF confirmou a competência da Justiça Militar para processar e julgar crime de ameaça de um militar da ativa contra sua ex-companheira, também militar da ativa, assistindo razão ao acórdão da Corte Castrense que afirmou:

“...apesar da alegação Defensiva no sentido de que os acontecimentos se deram no âmbito familiar e até mesmo na intimidade do casal, eles também tiveram desdobramentos na Caserna, uma vez que os fatos geradores da condenação ocorreram quando a Ofendida estava de serviço na $\mathrm{OM}$ e na presença de outros militares, o que inevitavelmente atrai a competência desta Justiça especializada para o julgamento do feito". (Grifo no original) (BRASIL, 2015, p.3)

A decisão do STF, nesse caso, apenas seguiu o raciocínio que a Corte vem proferindo nos julgamentos de outras matérias que envolvem conflito de competência com a Justiça Militar, nos quais ensina a Suprema Corte que não basta a condição de militar dos sujeitos para ficar configurada a competência da justiça especializada. Há de ser observado se o delito foi praticado em lugar sujeito à Administração Militar e se o agente afrontou a instituição militar, seus valores e princípios. Com base nesses critérios, dois julgados do STF - um atribui a competência à Justiça Militar e, o outro, retira a competência dessa Corte -, a saber:

A orientação do Supremo Tribunal Federal é no sentido de que a condição de militar da vítima e do agressor não é suficiente para atrair a competência da Justiça Militar. Precedentes. No caso, contudo, a subtração dos cartões magnéticos e um dos saques bancários ocorreram dentro de unidade sujeita à administração militar, em momento no qual o paciente e as vítimas estavam em serviço militar, não sendo possível afastar a competência da Justiça especializada. 3. Ordem denegada. (Grifo nosso) (BRASIL. Supremo Tribunal Federal. Habeas Corpus 122302/ MG. Relator: Roberto Barroso. Data de Julgamento: 20 mai. 2014. Brasília: Diário de Justiça Eletrônico, 05 jun. 2014.)

2. Ementa: HABEAS CORPUS. PENAL MILITAR. FURTO SIMPLES. ART. 240 DO CPM. NÃO CARACTERIZAÇÃO DE CRIME MILITAR (ART. 9', II, 'A', DO CPM). COMPETÊNCIA DA JUSTIÇA ESTADUAL COMUM. ORDEM CONCEDIDA. 1. A caracterização do crime militar em decorrência da aplicação do critério ratione personae previsto no art. $9^{\circ}$, II, "a", do CPM deve ser 
compreendido à luz da principal diferença entre o crime comum e o crime militar impróprio: bem jurídico a ser tutelado. Nesse juízo, portanto, torna-se elemento indispensável para configuração do tipo penal especial (e, portanto, instaurar a competência da Justiça Militar da União) a demonstração de ofensa a bens jurídicos de que sejam titulares as Forças Armadas. Daí a convergência de entendimento, na jurisprudência do STF, de que o delito cometido fora do ambiente castrense ou cujo resultado não atinja as instituições militares será julgado pela Justiça comum. Precedentes. (...) (Grifo nosso)

(BRASIL. Supremo Tribunal Federal. Habeas Corpus 117254/PR. Relator: Teori Zavascki. Data de Julgamento: 30 set. 2014. Brasília: Diário de Justiça Eletrônico, 15 out. 2014.)

Diante do exposto, e observando os ensinamentos doutrinários e jurisprudenciais, parece que a solução razoável para o conflito de competência entre a Justiça Comum e a Justiça Militar para julgamento dos casos de violência doméstica e familiar entre casais de militares seria aquela que pondera a relevância de se proteger a mulher vitimizada pelo cônjuge, ambos militares, e também a que não olvida a importância de se tutelar e preservar os bens jurídicos do direito militar, quando afrontados.

Pois bem, a Lei da Maria da Penha é a legislação eficiente para proteger a mulher que se encontra em situações de violência familiar e é ela que deve tutelar todas as mulheres que dela necessitam, independente da profissão militar que exercem. Assim, as situações de violência doméstica e familiar que não atingem as instituições militares, nem foram praticadas sob a sua administração, sem dúvidas, devem ser processadas e julgadas pela Justiça Comum. Entretanto, se na análise do caso concreto verificar-se que a agressão foi cometida no âmbito da caserna e representa ofensa a bens jurídicos e valores militares, não se pode esquecer da tutela desses bens jurídicos.

\section{CONCLUSÃO}

Apresentando-se o atual cenário da Lei Maria da Penha, das mulheres nas instituições militares e dos argumentos da doutrina e jurisprudência acerca da 
competência para julgamento dos casos de violência doméstica e familiar entre cônjuges militares, buscou-se destacar esta pequena - mas que vem ganhando cada vez mais espaço - parcela feminina da sociedade, qual seja, as mulheres que decidiram seguir a carreira militar, bem como o lamentável quadro de agressões de gênero nas relações íntimas e, especificamente, a controvérsia da competência para julgamento desses casos, entre a Justiça Comum e a Justiça Militar. Em outras palavras, agressões contra a mulher militar por cônjuge também militar, decorrente de relação familiar, são tuteladas pela Lei Maria da Penha ou pela Justiça Militar?

Verificou-se, com base na posição da doutrina e na jurisprudência, que a posição que tenta ponderar todos os bens jurídicos envolvids seria, em regra, atribuir tal competência à Justiça Comum, aplicando-se a Lei Maria da Penha, uma vez que tal legislação possui os instrumentos necessários e eficazes para salvaguardar a mulher vitimizada. Do contrário, a não aplicação da lei especial seria uma discriminação com a mulher que escolheu a profissão militar, segregando-a de todas as outras mulheres da sociedade civil. Em que pese a farda que veste o casal, a agressão, a priori, tem motivações de foro íntimo, decorrente da relação afetiva, que não atingem os bens jurídicos das instituições militares. Assim, a competência deve ser da Justiça comum, visto que apenas a situação de militar da ativa dos sujeitos não basta para configurar a competência da Corte Castrense.

Apenas quando as instituições militares forem afrontadas em decorrência de violência doméstica e familiar contra a mulher que é militar e seu cônjuge também, a competência poderá ser da Justiça especializada, garantindo-se a ela a utilização das medidas protetivas da Lei Maria da Penha. É essencial cuidar da situação apresentada da mulher, valorizando-se a Lei Maria da Penha e não apartando a profissional militar das demais mulheres. Não obstante a primeira ter designado sua vida em favor da nação ou da segurança da sociedade, ela deve ser tão protegida quanto as demais. Todavia, cediço é que não existe nenhum direito absoluto, nem mesmo os direitos fundamentais. Dessa forma, é preciso encontrar um equilíbrio a fim de que a Justiça 
Militar cumpra seu papel e mantenha a regularidade das instituições militares que salvaguardam o próprio Estado Democrático de Direito. Cumpre assim, para decidir cada situação, analisar o caso concreto na busca da melhor tutela jurídica, relembrado, ante o exposto, que o presente trabalho não pretendeu exaurir o tema, mas sim trazer à tona o debate na busca de uma adequada e ponderada solução para a questão aqui discorrida.

\section{REFERÊNCIAS}

ADÃO, Maria Cecília Oliveira; MATHIAS, Suzeley Kalil. Mulheres e Vida Militar. Cadernos Adenauer XIV (2013) no3. 2013. Disponível em: <http://www.kas.de/brasilien/pt/pages/6508>. Acesso em: 02 nov. 2016.

ALMEIDA, Vítor Hugo de Araújo. Mulheres nas Forças Armadas brasileiras: situação atual e perspectivas futuras. Consultoria Legislativa Estudo maio/2015. Portal da Câmara dos Deputados. 2015. Disponível em:

<http://www2.camara.leg.br/documentos-e-pesquisa/publicacoes/estnottec/areas-daconle/tema21/2015_291_estudo-sobre- mulheres-nas-forcas-armadas-vitor-hugo>. Acesso em: 02 nov. $201 \overline{6}$.

ALVES-MARREIROS, Adriano. Casal de Militares e CPM: Discussão sobre família, proteção da mulher e Lei Maria da Penha. Gen Jurídico, 2015. Disponível em: <http://genjuridico.com.br/2015/05/29/casaldemilitaresecpmdiscussaosobrefamiliaprotec aodamulhereleimariadapenha/>. Acesso em: 5 nov. 2016.

ASSIS, Jorge Cesar de. Casal de militares: Lei Maria da Penha e a aplicação de seus institutos protetivos ao Direito Castrense. Jus Militaris, 2015. Disponível em: $<$ www.jusmilitaris.com.br>. Acesso em: 6 nov. 2016.

. Comissão de Gênero debate Plano Nacional de Ação. Portal do Ministério da Defesa. Brasília, 2016. Disponível em: <http://www.defesa.gov.br/noticias/23215comissao-de-genero-debate-plano-nacional-de-acao>. Acesso em: 5 nov. 2016.

. Constituição da República Federativa do Brasil. Brasília, 1988. Disponível em:

<http://www.planalto.gov.br/ccivil_03/Constituicao/Constituicao.htm>. Acesso em: 27 out. 2016. 
Lei no 6.880 , de 9 de dezembro de 1980. Dispõe sobre o Estatuto dos Militares.Disponível em: <http://www.planalto.gov.br/ccivil_03/Leis/L6880.htm>. Acesso em: 4 nov. 2016.

Lei no 11.340, de 7 de agosto de 2006. Cria mecanismos para coibir a violência doméstica e familiar contra a mulher, nos termos do $\S 80$ do art. 226 da Constituição Federal, da Convenção sobre a Eliminação de Todas as Formas de Discriminação contra as Mulheres e da Convenção Interamericana para Prevenir, Punir e Erradicar a Violência contra a Mulher; dispõe sobre a criação dos Juizados de Violência Doméstica e Familiar contra a Mulher; altera o Código de Processo Penal, o Código Penal e a Lei de Execução Penal; e dá outras providências. Disponível em: <http://www.planalto.gov.br/ccivil_03/_Ato2004-2006/2006/Lei/L11340.htm>. Acesso em: 29 out. 2016.

- Secretaria Nacional de Segurança Pública (SENASP). Mulheres nas Instituições de Segurança Pública: Estudo Técnico Nacional. Brasília, 2013. Disponível em:

<http://bibspi.planejamento.gov.br/handle/iditem/299>. Acesso em: 4 nov. 2016.

Superior Tribunal Militar. Apelação 00000472420147120012/AM.Relator: Marco Antônio de Farias. Data de Julgamento: 17 ago. 2016. Brasília: Diário de Justiça Eletrônico, 29 ago. 2016.

Disponível em:

<http://stm.jusbrasil.com.br/jurisprudencia/379797373/apelacao-ap-472420147120012-

am>. Acesso em: 6 nov. 2016.

. Supremo Tribunal Federal. Ação Declaratória de Constitucionalidade 19/DF. Relator : Marco Aurélio. Brasília, 9 fev. 2012. Disponível em:

$<$ http://redir.stf.jus.br/paginadorpub/paginador.jsp?docTP=TP\&doclD=5719497>. Acesso em: 3 jul. 2017.

. Supremo Tribunal Federal. Ação Direta de Inconstitucionalidade 4.424/DF. Relator: Marco Aurélio. Brasília: Diário de Justiça Eletrônico, 9 fev. 2012.Disponível em: $<$ http://redir.stf.jus.br/paginadorpub/paginador.jsp?docTP=TP\&doclD=6393143>.Acesso em: 3 jul. 2017.

Supremo Tribunal Federal. Habeas Corpus 122302/MG. Relator: Roberto Barroso. Data de Julgamento: 20 mai. 2014. Brasília: Diário de Justiça Eletrônico, 05 jun. Disponível em: <http://stf.jusbrasil.com.br/jurisprudencia/25110530/habeas-corpushc-122302-mg-stf>. Acesso em: 6 nov. 2016. 
Supremo Tribunal Federal. Habeas Corpus 117254/PR. Relator: Teori Zavascki. Data de Julgamento: 30 set. 2014. Brasília: Diário de Justiça Eletrônico, 15 out. 2014.). Disponível em: <http://stf.jusbrasil.com.br/jurisprudencia/25294836/habeascorpus-hc-117254-pr-stf>. Acesso em: 6 nov. 2016.

. Supremo Tribunal Federal. Habeas Corpus 125836/SP. Relator: Dias Toffoli. Brasília, 02 fev. 2015. Disponível em:

<http://stf.jusbrasil.com.br/jurisprudencia/25354042/medida-cautelar-no-habeas-corpushc-125836-sp-stf>. Acesso em: 7 nov. 2016.

. Superior Tribunal de Justiça. Jurisprudência em Teses. Violência doméstica e familiar contra mulher.Edição oㅜ 41. Brasília, 16 set. 2015. Disponível em:

$<$ http://www.stj.jus.br/internet_docs/jurisprudencia/jurisprudenciaemteses/Jurisprud\%C3 \%AAncia\%20em\%20teses\%2041\%20-\%20Lei\%20Maria\%20da\%20Penha.pdf>. Acesso em: 27 out. 2016.

DIAS, Maria Berenice. Lei Maria da Penha, afirmação da igualdade. Migalhas, 2007. Disponível em:

<http://www.migalhas.com.br/dePeso/16,Ml47058,71043-

lei+Maria+da+Penha+afirmacao+da+igualdade>. Acesso em: 6 nov. 2016.

JURISPRUDÊNCIA do STF é destaque nos 10 anos da Lei Maria da Penha. Portal do Supremo Tribunal Federal, Brasília, 8 agosto. 2016. Disponível em: <http://www.stf.jus.br/portal/cms/verNoticiaDetalhe.asp?idConteudo=322468>. Acesso em: 30 out. 2016.

Lei Maria da Penha: Aspectos fundamentais da lei. Observe - Observatório Lei Maria da Penha. Disponível em: <http://www.observe.ufba.br/lei_aspectos>. Acesso em: 4 nov. 2016.

Lei Maria da Penha vale para homens? Olhar Jurídico, 2015. Disponível em: <http://www.olhardireto.com.br/juridico/noticias/exibir.asp?id=23652>. Acesso em: 29 out. 2016.

LOBÃO, Célio. Direito Penal Militar. 3ª̣ ed. atual. Brasília: Brasília Jurídica, 2006.

MULHERES vencem resistências históricas e conquistam espaço nas Forças Armadas. Portal Brasil, Brasília, 8 mar. 2016. Disponível em: <http://www.brasil.gov.br/cidadaniae-justica/2016/03/mulheres-vencem-resistencias-historicas-e-conquistam-espaco-nasforcas-armadas>. Acesso em: 4 nov. 2016. 
NEVES, Cícero Robson Coimbra; STREIFINGER, Marcello. Manual de Direito Penal Militar. 2. ed. São Paulo: Saraiva, 2012.

NUCCI, Guilherme de Souza. Código Penal Militar Comentado. $2^{\underline{a}}$ ed. Rio de Janeiro: Editora Forense, 2014.

OEA condena Brasil por violência doméstica. Folha de São Paulo, São Paulo, 6 maio. 2001. Disponível em:

<https://www1.folha.uol.com.br/fsp/cotidian/ff0605200109.htm>. Acesso em: 5 nov. 2016.

ORGANIZAÇÃO DOS ESTADOS AMERICANOS (OEA). Convenção Interamericana para prevenir, punir e erradicar a violência contra a mulher, "Convenção de Belém do Pará". Belém (PA), 9 jun. 1994. Disponível em:

$<$ https://www.cidh.oas.org/basicos/portugues/m.Belem.do.Para.htm>. Acesso em: 1 nov. 2016.

ROCHA, Maria Elizabeth Guimarães Teixeira. A Lei Maria da Penha e o Direito Penal Militar. Compromisso e Atitude, 2015. Disponível em:

http://www.compromissoeatitude.org.br/a-lei-maria-da-penha-e-o-direito-penal-militarpor-maria-elizabeth-guimaraes-teixeira-rocha/. Acesso em: 5 nov. 2016.

VICENTE, Paulo; ALEXANDRINO, Marcelo. Direito Constitucional Descomplicado. 14aㅡ ed. São Paulo: Editora Método, 2015. 